Original Paper http://ajol.info/index.php/ijbcs http://indexmedicus.afro.who.int

\title{
Morphological and molecular identification of fungi associated with corm rot and blight symptoms on plantain (Musa paradisiaca) in macro-propagators
}

\author{
Eneke Tambe BECHEM* and Yannick Afanga AFANGA
}

\author{
Department of Botany and Plant Physiology, Faculty of Science, University of Buea P.O. Box 63 Buea, \\ Cameroon. \\ *Corresponding author; E-mail: tamenekeso@yahoo.co.uk; Tel: +237677358523
}

\begin{abstract}
Plantain is a major staple food crop for millions of people in Cameroon and contributes significantly to food security. A limiting factor to large-scale production of plantains is the difficulty in obtaining healthy planting materials. Macro-propagation technology, which has the potential to produce 50-60 shoots per sucker in 4-5 months, was introduced to bypass this difficulty. The aim of this study was to isolate and identify the fungi growing in plantain propagators in Buea municipality, which could probably be responsible for the corm rot and blight symptoms observed. Fungi were isolated from the corm, root, pseudostem, leaves and from fruiting bodies on Potato dextrose agar. Isolates were characterized using cultural, micro-morphological and molecular techniques. A total of 5 isolates were obtained, most of which were whitish in colour and all had septate hyphae, belonging to the Ascomycota. The molecular weight of the DNA of the isolates ranged between 500-800 bp. Based on sequence similarity, these isolates were identified to belong to five species viz: Alternaria burnsii, Fusarium oxysporum, Chaetomium globosum, Hypocrea lixii and Trichoderma harzianum. Of these five isolates, $F$. oxysporum was the only one that had been reported to be the causal agent of Fusarium wilt (Panama) disease of plantain. Fusarium and Chaetomium are likely responsible for the diseased symptoms observed. Proper management and control of these fungal species in propagators will permit the production of healthy seedlings, thus enabling large scale production of plantains.
\end{abstract}

(C) 2017 International Formulae Group. All rights reserved.

Keywords: Plantain, Fusarium, corm rot, blight, Chaetomium.

\section{INTRODUCTION}

Bananas and plantains are major staple food crops for millions of people in Cameroon and do contribute significantly to food security. They serve as raw materials for many popular delicacies and snacks (Ngoh et al., 2005). However, the productivity and lifespan of banana and plantain fields have drastically reduced due to pest and disease pressure. The decline was attributed mainly to an increase in the prevalence of pests and diseases combined with lack of effective control strategies (Kahangi et al., 2004). The major diseases have been Fusarium wilt caused by Fusarium oxysporum f. sp. cubense (Foc); Black and Yellow sigatoka leaf spot caused by Mycosphaerella fijiensis and Mycosphaerella musicola respectively, weevils (Cosmopolites sordidus) and plant parasitic nematodes. This problem is made 
intense because farmers usually depend on natural regeneration of plants for the supply of planting materials, which are often contaminated by pests and diseases.

A common limiting factor to largescale production of bananas and plantains and/or expansion of existing plantation is the difficulty in obtaining planting materials (Baiyeri and Ajayi, 2000), which may be due to several diseases which are easily spread during the production of seedlings by vegetative propagation (Gandonou et al., 2012). Demand for pest free and high quality planting materials has been on the increase since they are required for the development of new plantations and expansion of the existing ones. As a result, tissue culture which was introduced in 1997, has been poorly adopted due to high costs of seedlings, capital requirements and skills involved (Njau et al., 2011).

As a consequence, macro-propagation technology was introduced as an alternative to tissue culture. The technology requires little capital and skill for implementation. Macropropagation has the potential to produce 50-60 shoots per sucker in 4-5 months (Singh et al., 2011). Fungi especially those belonging to Mycosphaerella cause the most important leaf diseases of banana and plantain worldwide (Koné, 2008).

An unidentified species of macroscopic fungus has been observed to infest propagators in the Buea municipality, South West Region, Cameroon. Propagators in which this fungus was found were characterized by corm rot as well as blight symptoms on the leaves of the plantlets, indicating a possible relationship between this macroscopic fungus and the symptoms observed.
Corm rot and blight have caused great losses in the production of suckers and plantlets, thus resulting to the scarcity of planting material. This has made some farmers who produced and sold planting materials for a living to abandon the business.

There is urgent need to identify the fungus and develop proper control measures. The objective of the study reported here was therefore to isolate, characterize and identify the macroscopic fungus as well as other fungi associated with diseased suckers in propagators.

\section{MATERIALS AND METHODS}

Study area

This study was carried out in Small Soppo and Mile 14 in Buea municipality, Fako Division, South West Region, Cameroon. Cameroon is located between latitude $4^{\circ} 8^{\prime \prime} 40 \mathrm{~N}-4^{\circ} 11^{\prime \prime}$ North of the equator and between longitude $9^{\circ} 16^{\prime \prime} 90 \mathrm{E}-9^{\circ}$ $17^{\prime \prime} 45 \mathrm{E}$ of the Greenwich meridian.

\section{Sample collection}

The propagation sites were visited; pictures of the symptoms on diseased plants and that of the macroscopic fungus were taken. This was followed by collection of samples. Samples were collected after. Samples were collected by cutting infected portions of the plantain suckers using a sterilized knife. Collections were from the roots, corms, pseudo-stems, leaves and the fruiting body of the macro-fungus. They were stored in damp tissue paper and transported in plastic bags to the University of Buea Life Science Laboratory, where they were immediately processed for fungal isolation. 


\section{Media preparation}

Potato dextrose agar (SIGMA) was used for the isolation of fungi, and was prepared following the manufacturer's instructions, in which $42 \mathrm{~g}$ of potato dextrose agar (PDA) was weighed and distilled water added to make $1000 \mathrm{ml}$. The medium was autoclaved at $121{ }^{\circ} \mathrm{C}$ for 15 minutes, allowed to cool to about $50{ }^{\circ} \mathrm{C}$ before the addition of $0.1 \mathrm{~g} / \mathrm{L}$ of streptomycin. The mixture was stirred by gently swirling the flask, before pouring into $9 \mathrm{~mm}$ diameter sterile Petri dishes. The medium was allowed to solidify before inoculation.

\section{Isolation of fungi Sample preparation}

Isolation of fungi was based on the method described by Hallman et al. (2007). The five samples from the corm, the root, the pseudostem, the leaves and the fruiting body were washed with running tap water to remove dust and debris adhering to them and surface sterilized with $70 \%$ ethanol for $1 \mathrm{~min}$. The infected portions were cut into small pieces of $1 \times 1 \mathrm{~cm}$ under aseptic conditions using a sterile scalpel. They were then immersed in $4 \%$ sodium hypochlorite solution for 3 mins. This was followed by rinsing with $70 \%$ alcohol for $1 \mathrm{~min}$. They were finally rinsed in several changes of sterile distilled water and blotted dry on sterile tissue paper. Each plate was inoculated with 4 pieces of the surface sterilized plant part and fruiting body. Inoculation was done in triplicates, giving a total of 30 plates. Plates were sealed with parafilm wax and incubated at room temperature $\left(25^{\circ} \mathrm{C}\right)$ in the dark for 7 days. Fungi growing out of the inoculants were subcultured on fresh PDA plates at room temperature.

\section{Sub-culture}

Fresh plates of PDA were prepared, distinct fungi colonies from primary cultures were cut out using a sterile scalpel, and then transferred to the fresh PDA plates to obtain pure cultures. Inoculated plates were sealed with parafilm wax and incubated at room temperature $\left(25^{\circ} \mathrm{C}\right)$, in the dark for 7 days.

\section{Cultural characterization}

From each fungus isolated in pure culture, $5 \mathrm{~mm}$ mycelia discs was transferred to the centre of sterile Petri dishes containing fresh PDA. Inoculated plates were incubated for 7 days. Colony diameter was measured using a graduated $30 \mathrm{~cm}$ ruler and the mean diameter was obtained through the following formula:

\section{Mean colony diameter $=$ \\ Sum of colony diameter in the 3 plates (1) Total number of replicates}

\section{Morphological characterization}

For macroscopic observation, the cultural appearances (colony colour, texture, margin, form, elevation and aerial hyphae) were noted on PDA. Colony colours were determined using Methuen handbook of colour chart (Kornerup and Wanscher, 1978). A laboratory manual and a pictorial atlas for identification of fungi by Watanabe (2002) were equally used in the description of colony morphology.

\section{Micro-morphological characterization}

For micro-morphological characterization, all isolates were cultured on PDA for seven days; hyphae were observed for the presence or absence of septa in order to determine their taxonomic classes. 


\section{Molecular characterization DNA extraction}

All isolates were grown in PDA for 7 days at $25^{\circ} \mathrm{C}$. A sterile tooth pick was used to collect and transfer a small lump of mycelia from the pure culture into a $1.5 \mathrm{ml}$ eppendorf tube containing a lysis buffer $(400 \mathrm{mM}$ Tris-HCL (pH 8), 60 mM EDTA- $\mathrm{pH} 8.0$, $150 \mathrm{mM} \mathrm{NaCl}$ and $1 \%$ sodium dodecyl sulphate). The tube was briefly vortexed to disrupt the mycelia, after which it was maintained at room temperature for $10 \mathrm{~min}$. $150 \mu \mathrm{l}$ of potassium acetate was added into the eppendorf tube and this was followed by brief vortexing. The tube and contents were finally centrifuged at $>13,000 \mathrm{x}$ g for $1 \mathrm{~min}$. The supernatant was transferred to another $1.5 \mathrm{ml}$ eppendorf tube and centrifuged again as described above. The resulting supernatant was transferred into a new $1.5 \mathrm{ml}$ eppendorf tube and an equal volume of isopropyl alcohol was added. The tube was thoroughly mixed by inversion and centrifuged at $>13,000 \mathrm{x}$ g for 2 minutes and the supernatant was discarded. The resultant DNA pellet was washed in $300 \mu \mathrm{l}$ of $70 \%$ ethanol, after which it was spun at 10,000 rpm for $1 \mathrm{~min}$ and the supernatant was discarded. The DNA pellet was air dried and dissolved in $50 \mu 1$ of 1 xTris- EDTA. $1 \mu 1$ of purified DNA was used in $24 \mu 1$ of PCR mixture (Liu et al., 2000).

\section{PCR amplification}

Fungi were characterized by the amplification of their Internal Transcribed
Spacers (ITS). The forward (ITS-1F) and reverse (ITS-4R) primers (Table 1) used in the PCR reactions to amplify the ITS region of the rRNA operon have been described in Michaelsen et al. (2006).

Each PCR mixture contained $10 \mu$ of Red taq ready mix, $0.5 \mu 1$ of each primer pair, $8 \mu 1$ of analytical grade sterile water (SigmaAldrich) and $5 \mu$ of genomic DNA in a total volume of $24 \mu \mathrm{l}$. The thermocycling program used was an initial denaturation (94 ${ }^{\circ} \mathrm{C}$ for 5 minutes), 30 cycles of denaturation $\left(94{ }^{\circ} \mathrm{C}\right.$ for $\left.1 \mathrm{~min}\right)$, annealing $\left(60{ }^{\circ} \mathrm{C}\right.$ for 1 minute) and elongation $\left(72{ }^{\circ} \mathrm{C}\right.$ for 1 minute), then a stabilization $\left(72{ }^{\circ} \mathrm{C}\right.$ for 5 minutes) (Michaelsen et al., 2006). The genetic materials were electrophoresed on $2 \%$ agarose gel in Tris acetate- EDTA buffer and the gel was stained with ethidium bromide before observation in UV detector (Okoro et al., 2009). Approximated molecular sizes of the amplicons were determined using molecular weight marker $1 \mathrm{~kb}$ Plus DNA ladder (Invitrogen Carlsbad, California, USA).

\section{DNA sequencing}

Five amplicons were sent to Inqaba Biotechnical Industries (Pty) Ltd, Pretoria South Africa for sequencing. The sequences were then blasted against known sequences in the GenBank using BLAST (Basic alignment search tool) to find regions of local similarity between sequences in order to identify the species.

Table 1: The ITS primer pair used in this study.

\begin{tabular}{lc}
\hline Primer & Sequence 5' $\rightarrow \mathbf{3}$ \\
\hline ITS1 (forward) & TCCGTAGGTGAACCTGCGG \\
ITS4 (reverse) & TCCTCCGCTTATTGATATGC \\
\hline
\end{tabular}




\section{RESULTS}

\section{Macroscopic fungus, corm rot and blight symptoms observed}

The fungus was dark-brown in colour with hair-like structures (Figure 1). The leaves of the plantlets were yellowish with dark spots, all being symptoms of the blight (Figure 2a). When some of the plantlets were uprooted, we observed that the corms of some were rotten (Figure $2 b$ ).

A total of 5 fungal isolates were obtained in pure culturefrom the root, the corm, the pseudostem, the leaf and the fruiting body. It is worth noting that isolate $\mathrm{F}$ was obtained from all the plant parts as well as from the fruiting body (Table 2). Isolate $\mathrm{R}$ was present only in the roots; $\mathrm{P}$ was present only in the pseudostem and L only in the leaf. Isolate $\mathrm{C}$ was obtained from the corm, pseudostem and leaf (Table 2). The isolates and their codes are presented in Table 2.

\section{Morphological characterization}

The cultures of all isolates were whitish in colour with septate hyphae (Table $3)$.

Isolate $\mathrm{C}$ grew best, with an average colony diameter of $53.7 \mathrm{~mm}$ in 3 days. The margin was filiform, elevation was flat and the form was filamentous. Aerial hyphae were present and mycelia were whitish both on the surface and the reverse view (Table 3, Figure 3a).

Isolate $\mathrm{L}$ had an average colony diameter of $53.2 \mathrm{~mm}$. The margin was filiform, elevation was crateriform with a filamentous form. Aerial hyphae were present and the colour tint on the surface was white, while the reverse side showed a colour change from white to pale yellow (Table 3, Figure $4 a)$.

Isolate $\mathrm{R}$ showed the least growth with a colony diameter of $18.4 \mathrm{~mm}$. The margin of the isolate was entire, with a flat elevation and irregular form. Aerial hyphae were absent. The surface colour of mycelia was white just like the reverse colour (Table 3, Figure 5a).

Isolate $\mathrm{F}$ had an average colony diameter of $22.7 \mathrm{~mm}$, margin was filiform, and elevation was umbonate, with filamentous form. Aerial hyphae were present, with a surface colour tint which was white to grey while the reverse was brown to red (Table 3 , Figure 6a).

Isolate $\mathrm{P}$ had an average colony diameter of $27.4 \mathrm{~mm}$, margin was filiform, elevation was raised, form was filamentous and aerial hyphae were present. Mycelia were whitish but gradually turned to light brown (Table 3, Figure 7a).

\section{Identification of isolates}

Based on micro-morphological characters (Figures 3b-7b), all isolates were believed to belong to Phylum Ascomycota, since they all had septate hyphae which lacked clamp connections.

Isolate $\mathrm{C}$ produced large numbers of tiny spores (Figure $3 b$ ) just like isolate $\mathrm{L}$ (Figure $4 \mathrm{~b}$ ). Isolate $\mathrm{R}$ produced ascospores (Figure $5 \mathrm{~b}$ ) while isolate $\mathrm{F}$ showed an ascoma releasing spores (Figure $6 \mathrm{~b}$ ). Isolate $\mathrm{P}$ also had prominent hyphae as well as spore mass (Figure 7b).

\section{Molecular characterization DNA extraction}

DNA was successfully extracted from all the five isolates as indicated by the electrophoregram of genomic DNA which showed distinct bands for each isolate (lanes R, L, F, C, and P) as shown in Figure 8.

\section{Polymerase chain reaction (PCR)}

From the PCR products, the approximated molecular sizes of the amplicons were between $500 \mathrm{bp}$ and $800 \mathrm{bp}$ (Figure 9)

\section{Sequencing of PCR amplicons}

Sequencing of the five amplicons was successfully performed by Inqaba Biotechnical Industries (Pty) Ltd, Pretoria South Africa. Sequence analysis of the nuclear encoded rDNA showed significant alignments with 541/545 (99\%) identity in isolate P for Alternaria burnsii, 437/456 (96\%) identity in isolate C for Fusarium oxysporum, 359/361 
(99\%) identity in isolate $\mathrm{F}$ for Chaetomium globosum, 561/563 (99\%) identity in isolate L for Trichoderma harzianum, and 573/576 (99\%) identity in isolate R for Hypocrea lixii.

Based on sequence similarity to corresponding sequences in the GenBank, all the five isolates were identified to species as follows: Alternaria burnsii (KR604839.1) for isolate P, Hypocrea lixii (FJ461566.1) for isolate $\mathrm{R}, \quad$ Trichoderma hazianum
(KJ028794.1) for isolate L, Chaetomium globosum (KT780353.1) for isolate F and Fusarium oxysporum (KT877646.1) for isolate $\mathrm{C}$.

Overall, T. harzianum, H. lixii, and A. burnsii were each isolated from one sample only; Fusarium oxysporum was isolated from three samples while Chaetomium globosum was isolated from all the five samples (Table 4).

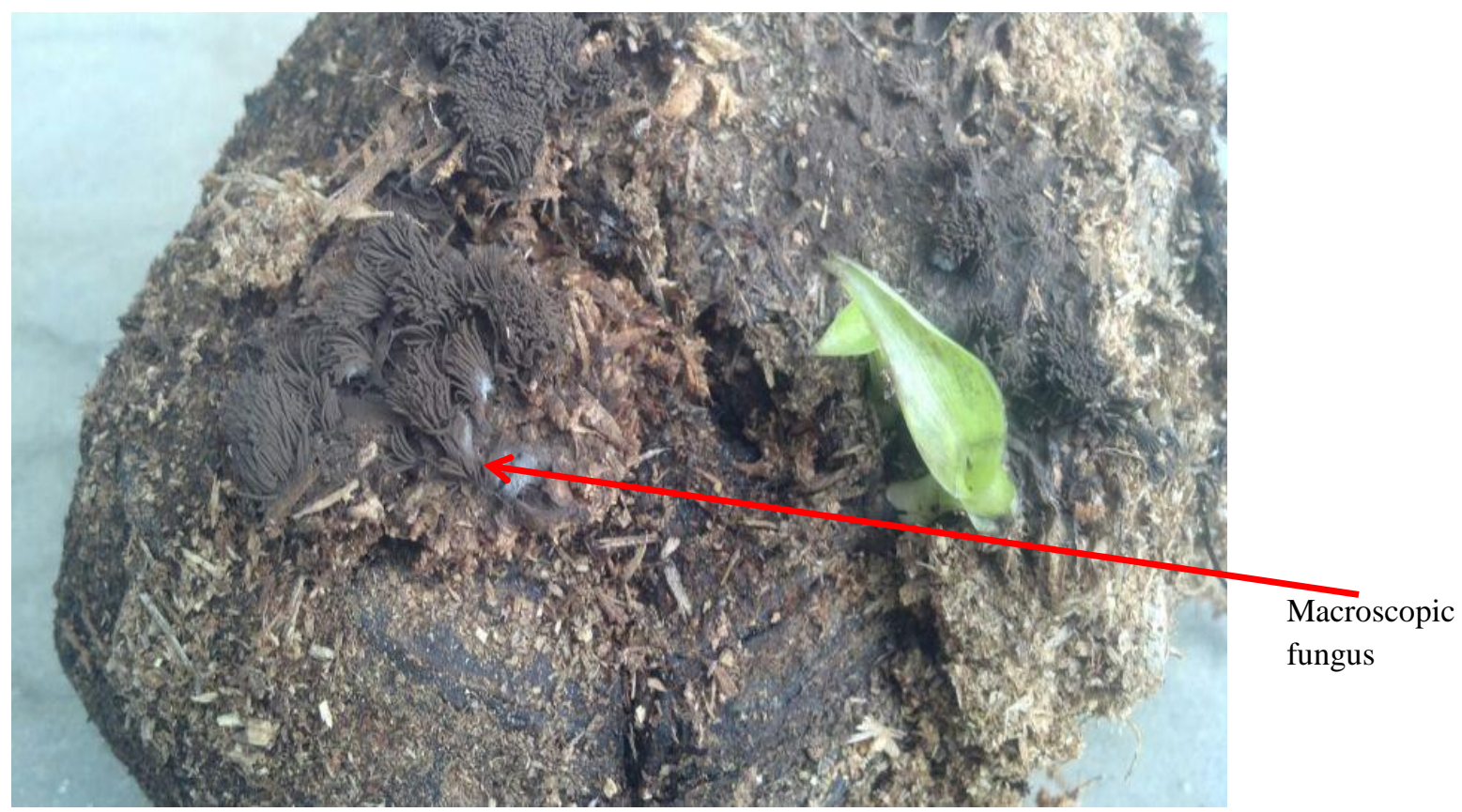

Figure 1: Macroscopic fungus observed on plantain corm.

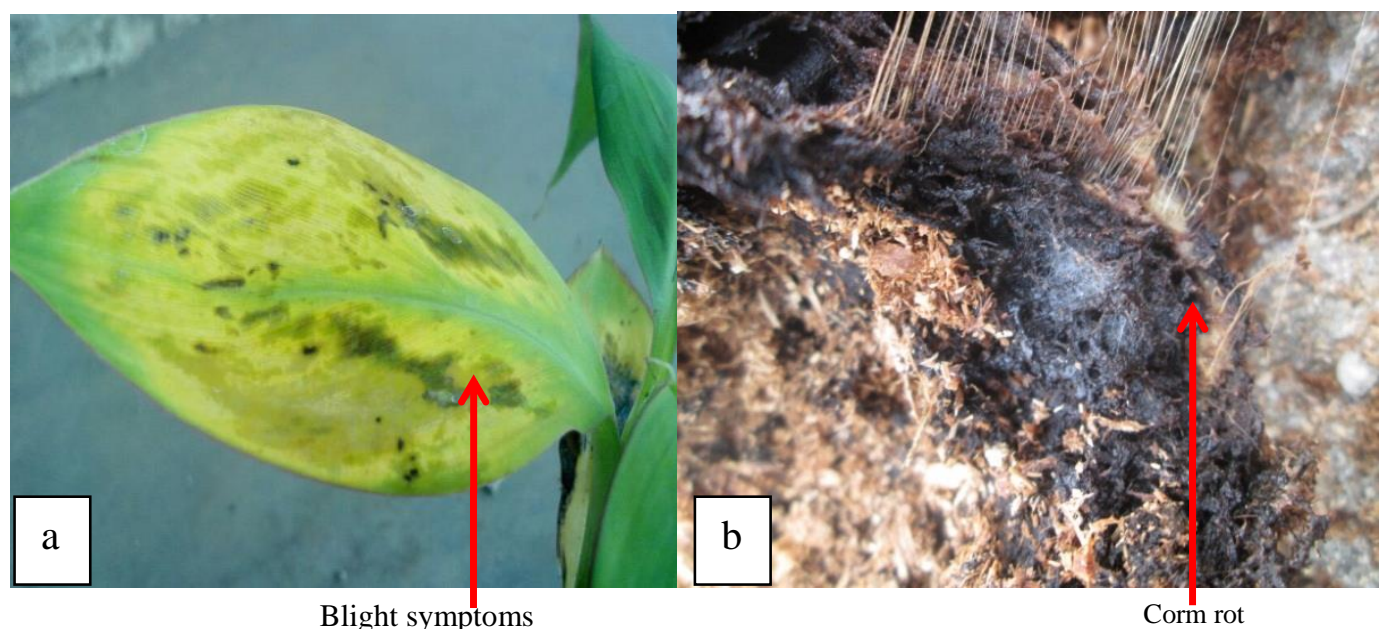

Figure 2: a- Blight symptoms observed on diseased plantlets. b- Corm rot observed in propagators. 
Table 2: Isolates obtained from the different plant parts and the fruiting body.

\begin{tabular}{lcc}
\hline Serial number & Plant parts & Isolate code \\
\hline 1 & Root & R, F \\
2 & Corm & C, F \\
3 & Pseudostem & P, F, C \\
4 & Leaf & L, F, C \\
5 & Fruiting body & F \\
\hline
\end{tabular}

Table 3: Cultural characteristics of fungi isolated from plantain parts and from fungi fruiting body.

\begin{tabular}{|c|c|c|c|c|c|c|c|}
\hline \multirow{2}{*}{$\begin{array}{l}\text { Isolate } \\
\text { code }\end{array}$} & \multirow{2}{*}{$\begin{array}{c}\text { Average } \\
\text { colony } \\
\text { diameter } \\
\text { (3days) }\end{array}$} & \multirow[t]{2}{*}{ Margin } & \multirow[t]{2}{*}{ Elevation } & \multirow[t]{2}{*}{ Form } & \multirow{2}{*}{$\begin{array}{c}\text { Aerial } \\
\text { hyphae }\end{array}$} & \multicolumn{2}{|c|}{ Colony tint } \\
\hline & & & & & & Surface & Reverse \\
\hline $\mathrm{C}$ & $53.7 \mathrm{~mm}$ & Filiform & Flat & Filamentous & Present & $\begin{array}{l}\text { Transparent to } \\
\text { white }\end{array}$ & White \\
\hline $\mathrm{L}$ & $53.2 \mathrm{~mm}$ & Filiform & Crateriform & Filamentous & Present & White & $\begin{array}{c}\text { White to pale } \\
\text { yellow }\end{array}$ \\
\hline $\mathrm{R}$ & $18.4 \mathrm{~mm}$ & Entire & Flat & Irregular & Absent & White & White \\
\hline $\mathrm{F}$ & $22.7 \mathrm{~mm}$ & Filiform & Umbonate & Filamentous & Present & White to grey & Brown to red \\
\hline $\mathrm{P}$ & $27.4 \mathrm{~mm}$ & Filiform & Raised & Filamentous & Present & White to brown & White \\
\hline
\end{tabular}

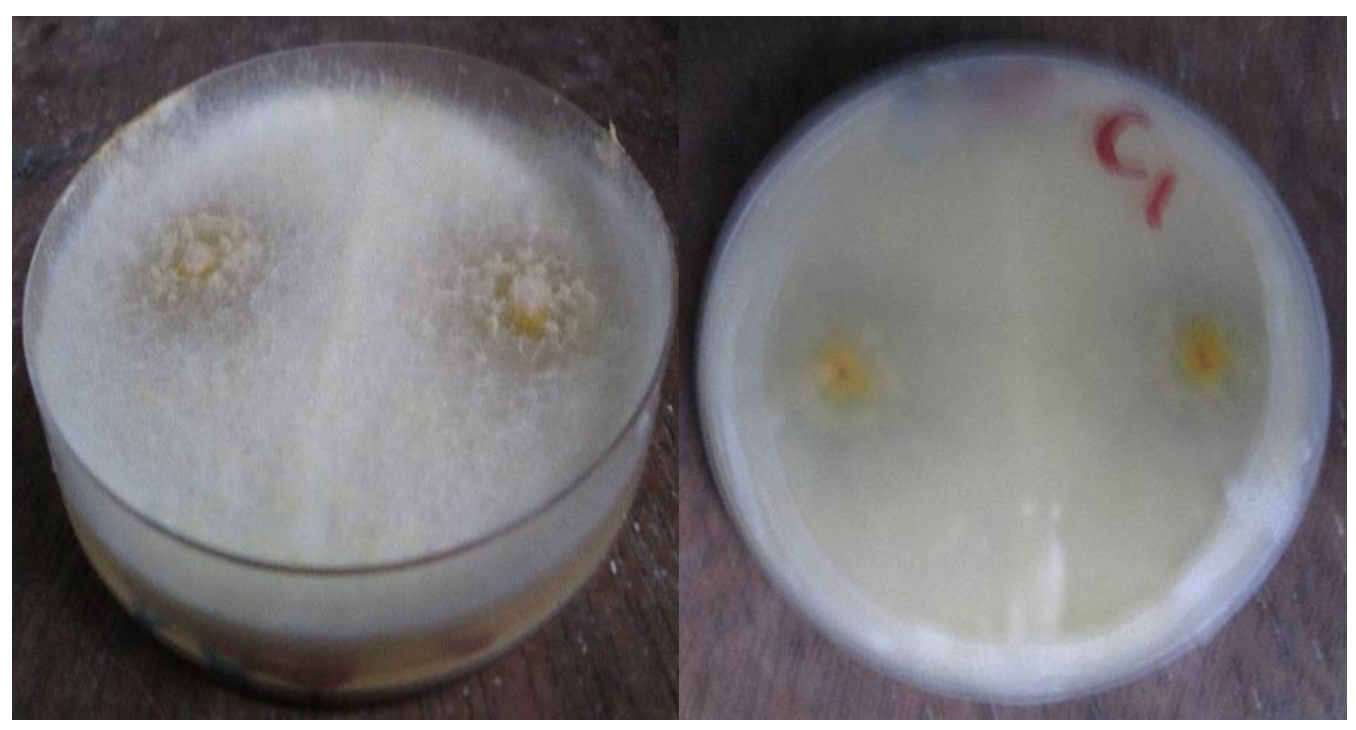

Figure 3a: Culture of isolate $\mathrm{C}$ on Potatoes Dextrose Agar (i) front view (ii) reverse view. 
E. T. BECHEM and Y. A. AFANGA / Int. J. Biol. Chem. Sci. 11(6): 2793-2808, 2017

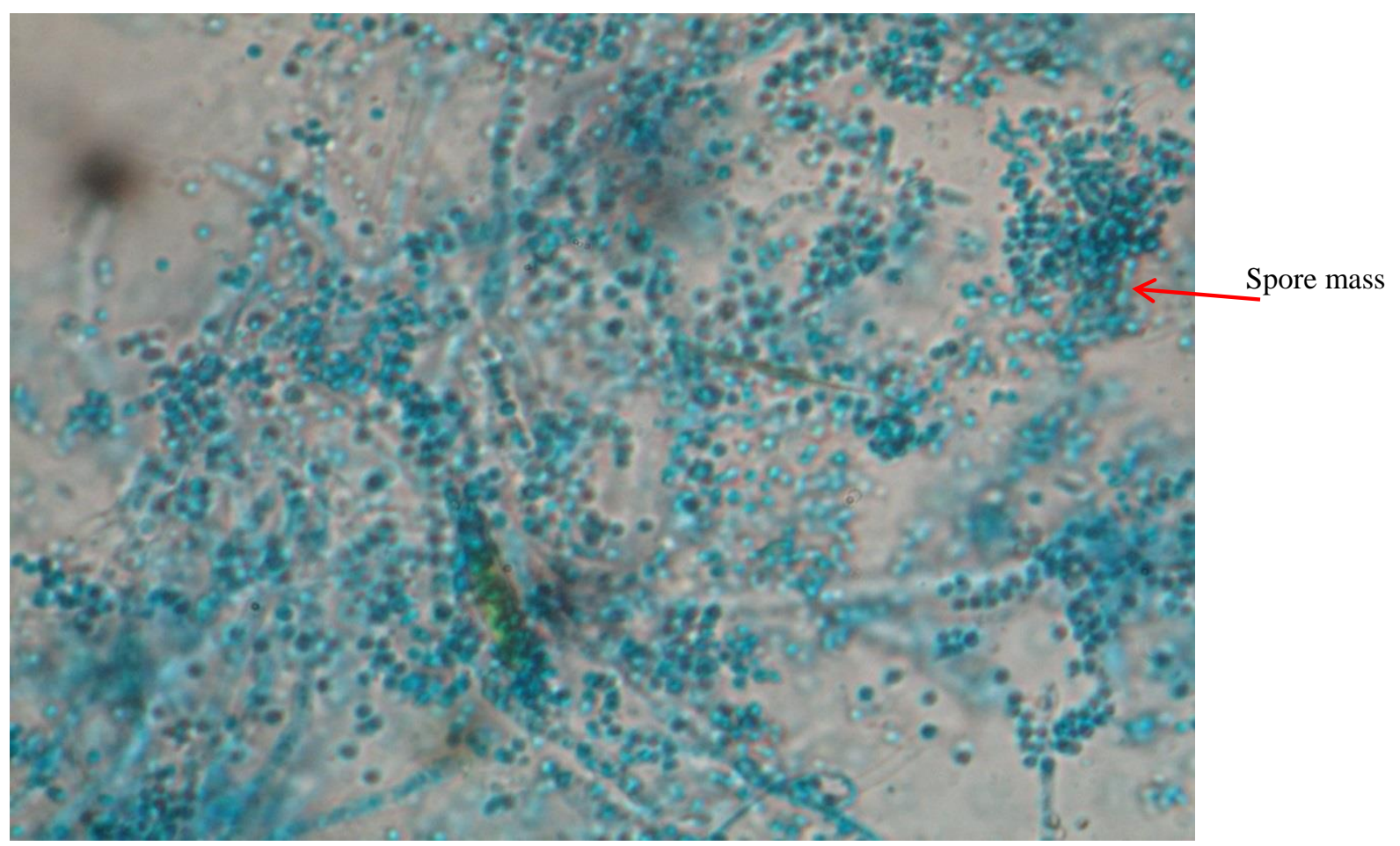

Figure 3b: Micro-morphological presentation of isolate C.

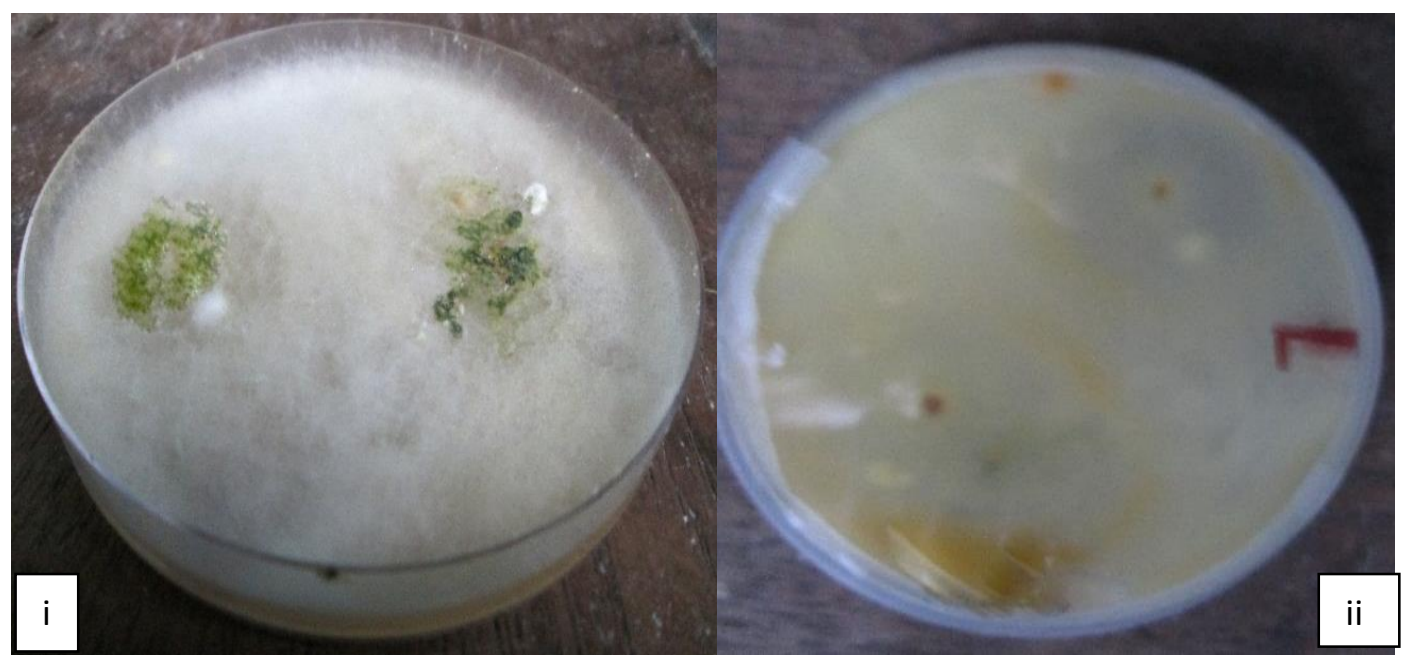

Figure 4a: Culture of isolate L on Potatoes Dextrose Agar (i) front view (ii) reverse view. 


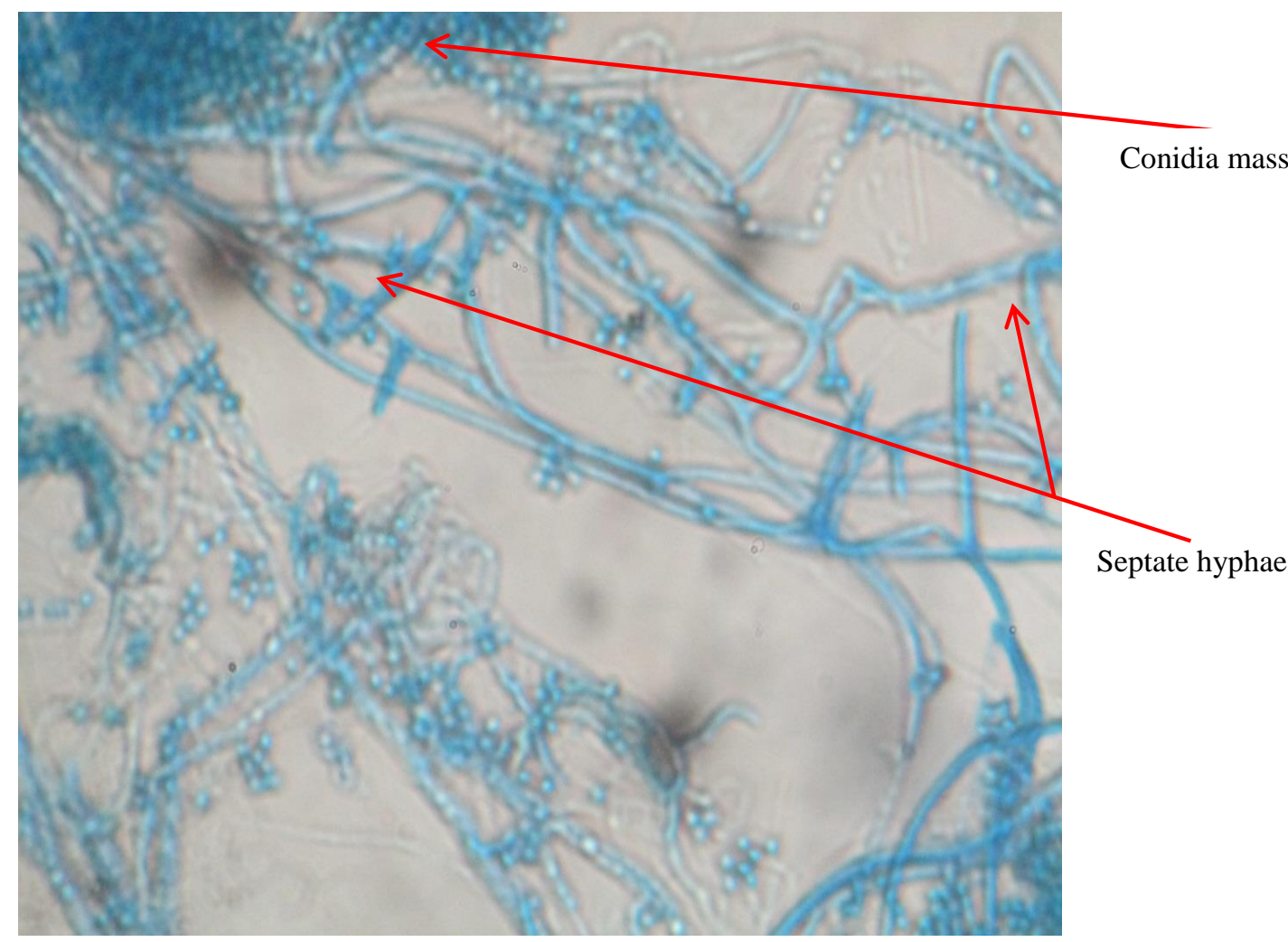

Figure 4b: Micro-morphological presentation of isolate L.

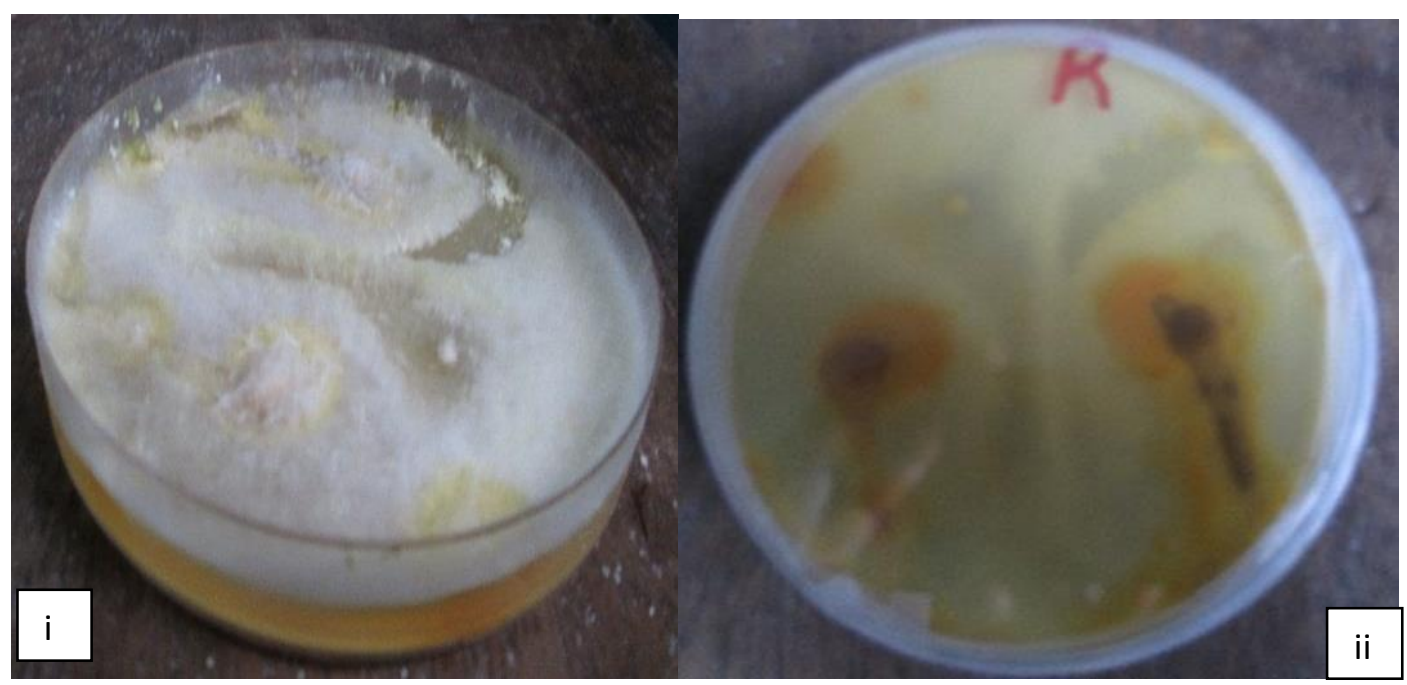

Figure 5a: Culture of isolate R on Potatoes Dextrose Agar (i) front view (ii) reverse view. 


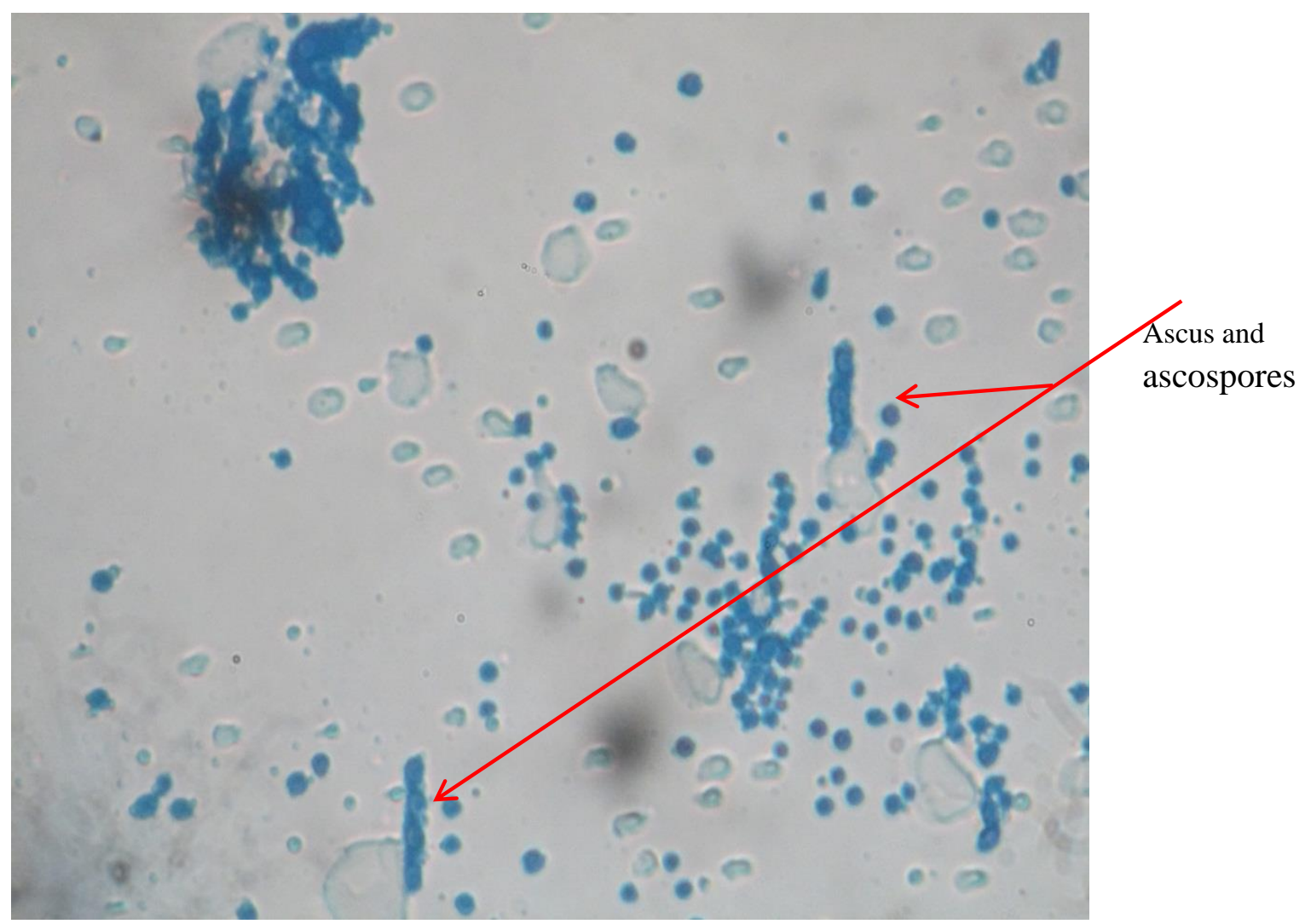

Figure 5b: Micro-morphological presentation of isolate R.

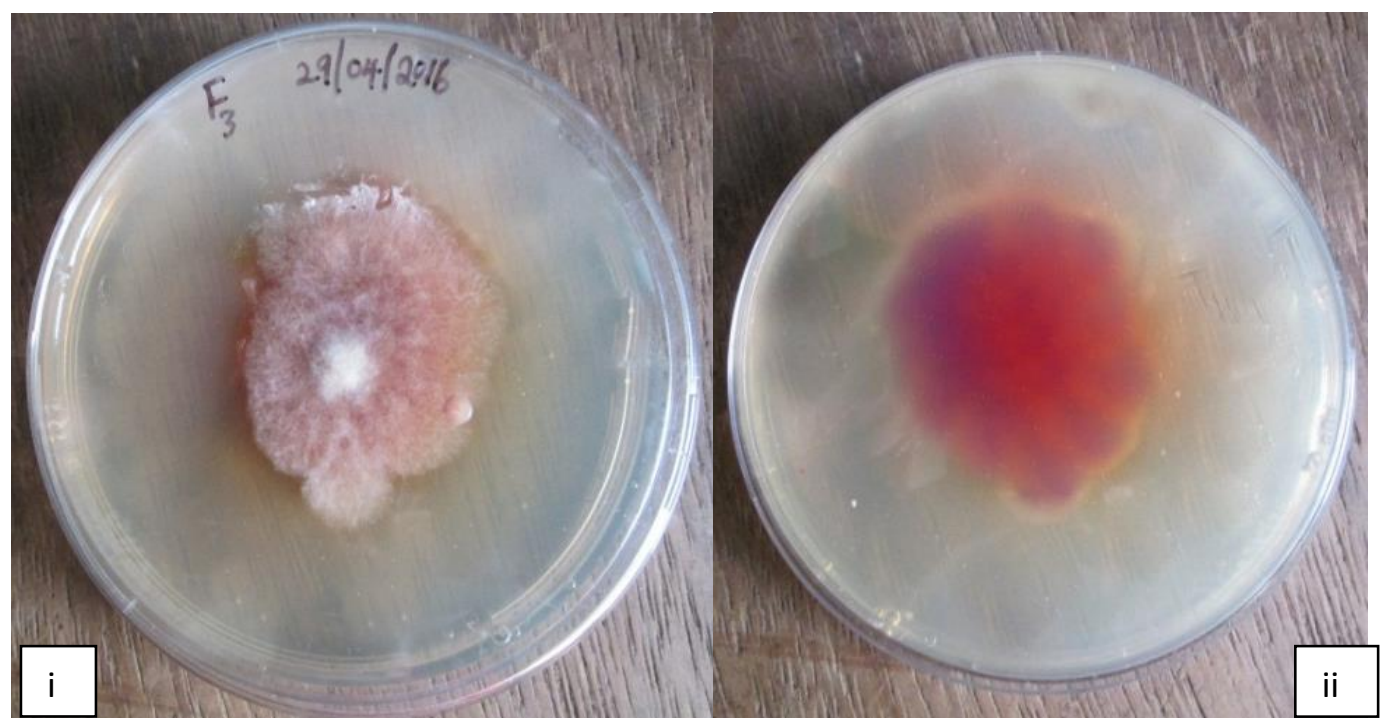

Figure 6a: Culture of isolate F on Potatoes Dextrose Agar (i) front view (ii) reverse view. 
E. T. BECHEM and Y. A. AFANGA / Int. J. Biol. Chem. Sci. 11(6): 2793-2808, 2017
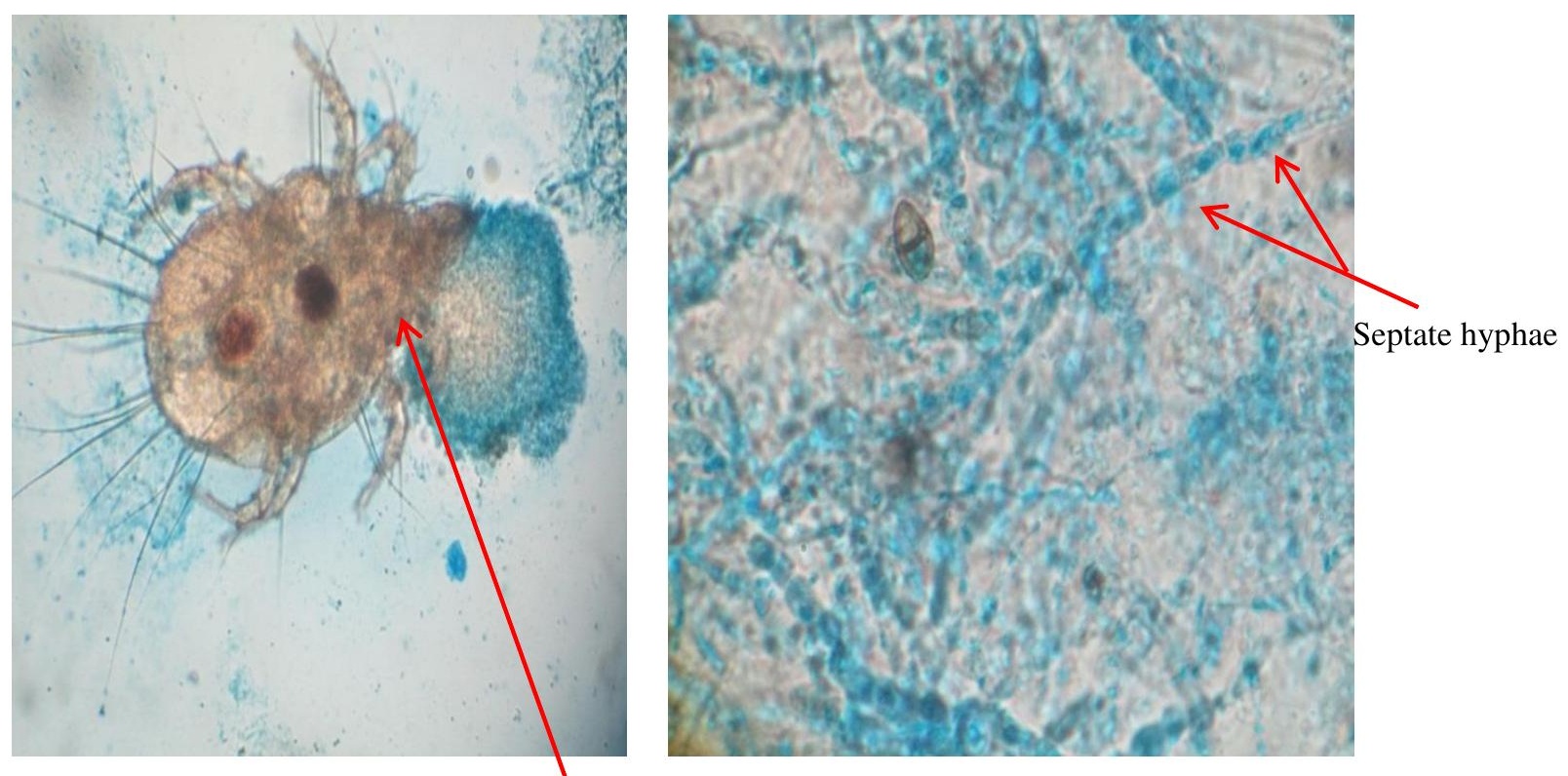

Ascoma releasing spores

Figure 6b: Micro-morphological presentation of isolate F.

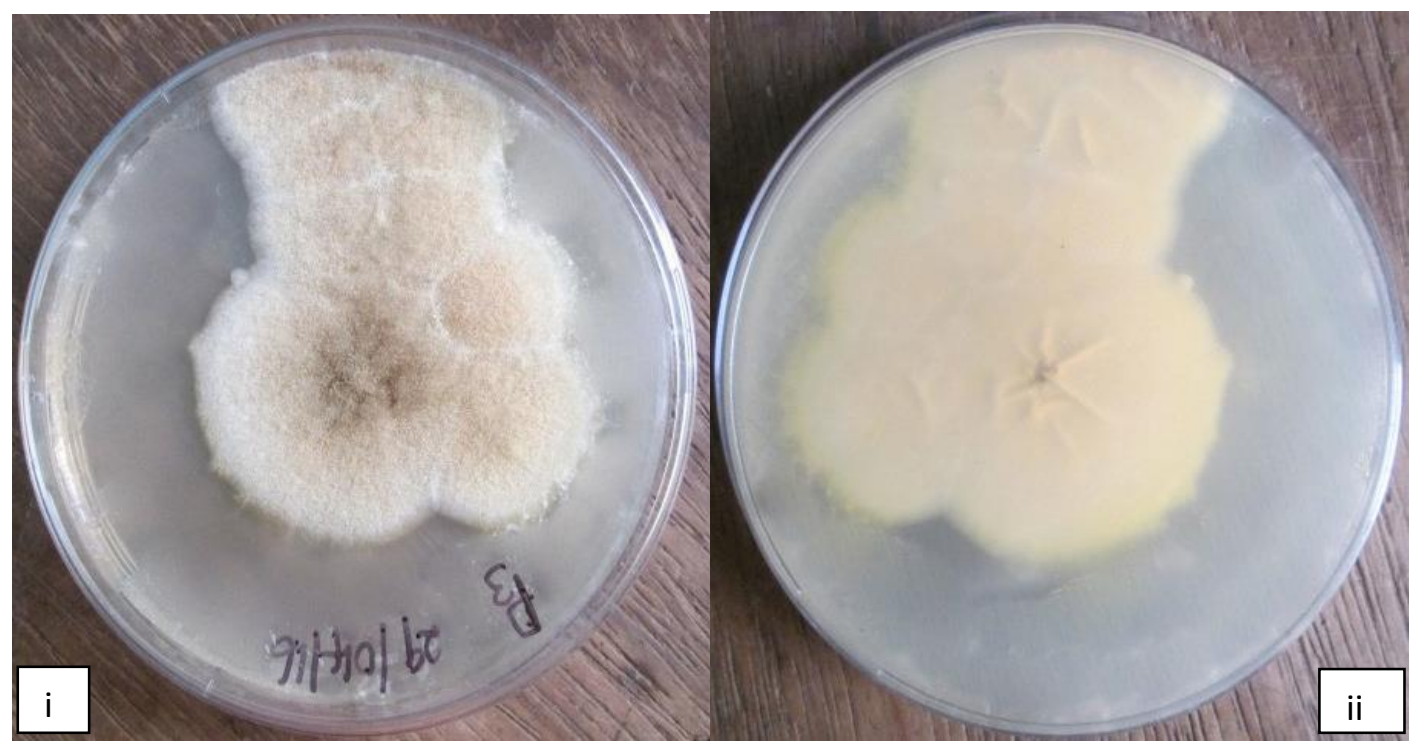

Figure 7a: Culture of isolate P on Potatoes Dextrose Agar (i) front view (ii) reverse view. 


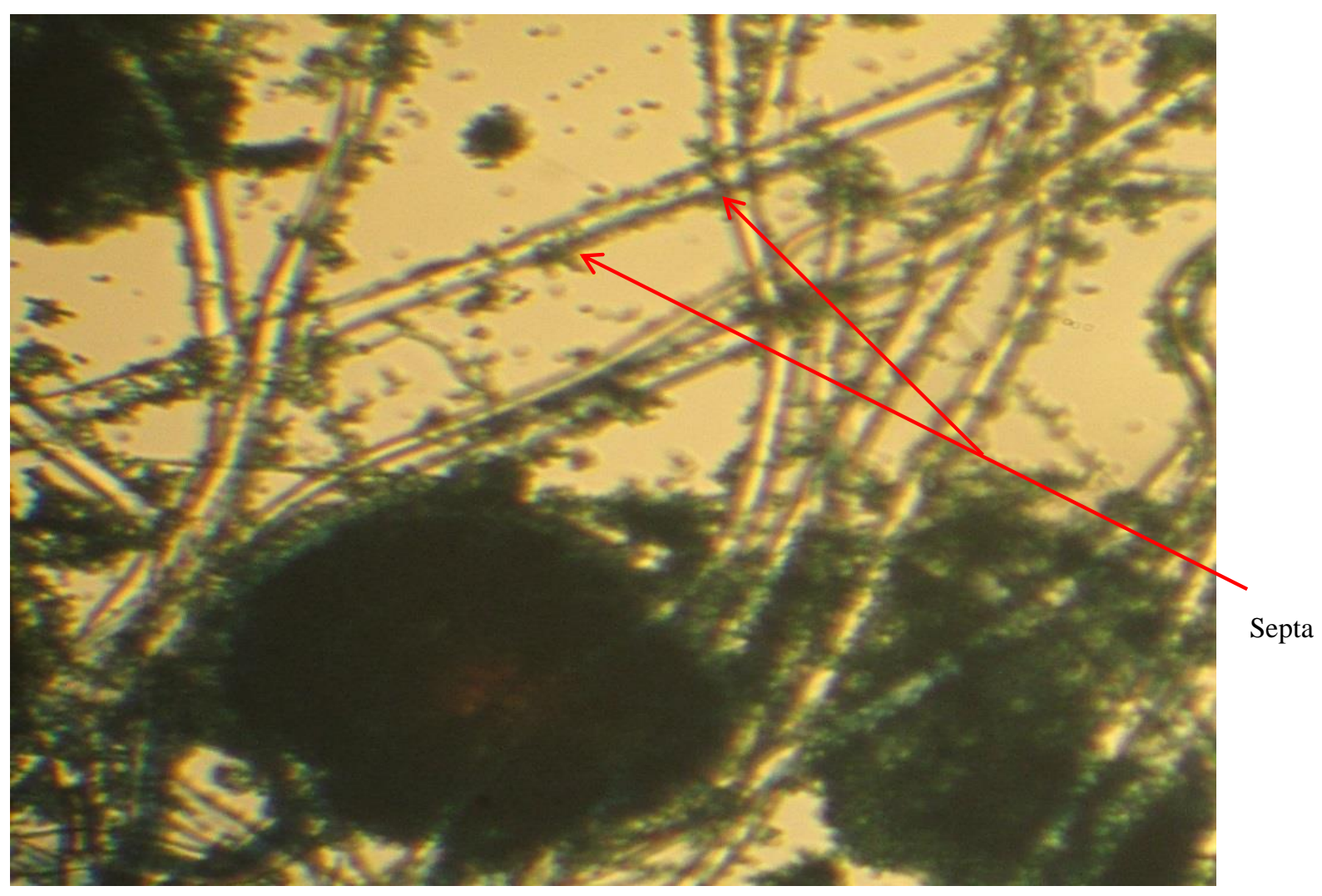

Figure 7b: Micro-morphological presentation of isolate $\mathrm{P}$.

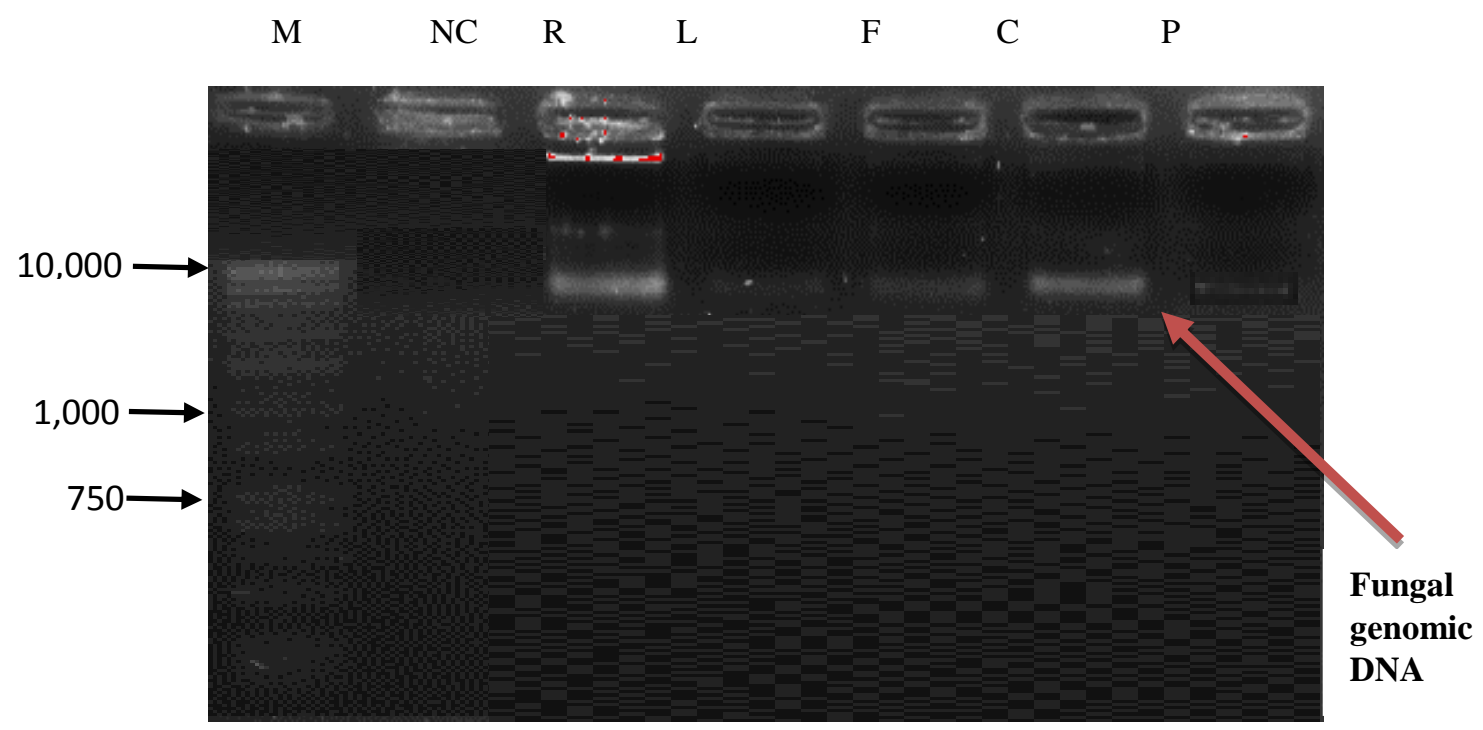

Figure 8: Electrophoregram of genomic DNA. Lane M: Molecular weight markers, NC: Negative control, P, R, L, F, and C are the PCR products of isolates P, R, L, F, and C. Samples were run on $2 \%$ agarose gel. 


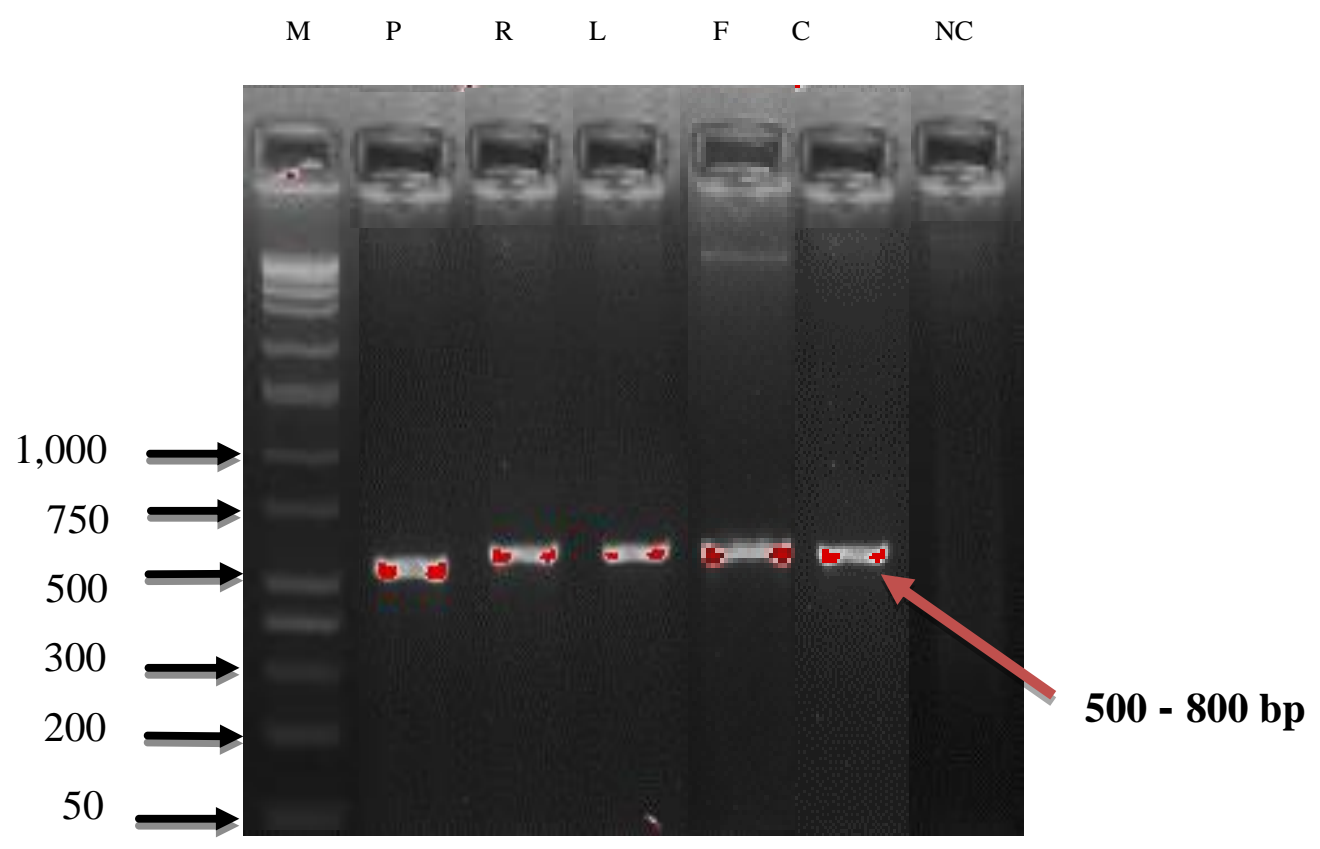

Figure 9: PCR products obtained from fungi isolates using ITS primer pair. Lane M: Molecular weight markers, NC: Negative control, P, R, L, F, and C are the PCR products of isolates P, R, L, F, and C. Samples were run on $2 \%$ agarose gel.

Table 4: Frequency of occurrence and percentage of the different fungi species, as isolated from the plant parts and fruiting body, on PDA containing streptomycin (100mg/L).

\begin{tabular}{llcc}
\hline Species & Plant parts & Frequency & \% Frequency \\
\hline Hypocrea lixii & Root & 1 & 20 \\
Chaetomium globosum & $\begin{array}{l}\text { Root } \\
\text { Corm } \\
\text { Pseudostem } \\
\text { Leaf } \\
\text { Fruiting body }\end{array}$ & 5 & 100 \\
& $\begin{array}{l}\text { Corm } \\
\text { Pseudostem } \\
\text { Leaf }\end{array}$ & 3 & \\
Fusarium oxysporum & Pseudostem & 1 & \\
Alternaria burnsii & Leaf & 1 & 20 \\
Trichoderma harzianum & & \\
\hline
\end{tabular}




\section{DISCUSSION}

Of all isolates identified, Fusarium oxysporum is the only one that has been reported as the causal agent of Fusarium wilt (Panama) disease of Plantain. This was confirmed by Ghag et al. (2015) who reported that Fusarium wilt disease of plantain/banana is caused by Fusarium oxysporum which invades the roots and stems tissues, blocking the water conducting channels and causing leaves to turn yellow, dry and eventually collapse.

So far, no literature has been encountered associating Chaetomium globosum with plantain. However, Biles et al. (2012) reported that Chaetomium globosum decomposes plant cells using hyphal cellulase activity. More to that, they are known to cause soft rot rather than brown rot, C. globosum plant decomposition leaves behind lignin residues (Biles et al., 2012). Therefore, $C$. globosum could also be a contributing factor to the corm rot observed in the macro propagators. Moreover, Abou and Shebany (2012) reported that C. globosum are endophytic to many plants. In spite of their ability to cause plant decomposition, their asymptomatic colonization in some plants, helps the plants to tolerate metal toxicity. When maize plants were treated with $C$. globosum, they expressed less growth inhibition and increased biomass (Abou and Shebany, 2012). C. globosum is also known to reside in Ginkgo biloba plants (Zhang et al., 2013). Sudarma and Suprapta (2011) isolated Chaetomium sp. from soil collected in a banana habitat, where the plants showed symptoms of Fusarium wilt in Indonesia. Interestingly in the same study, Chaetomium was not present in soils from a banana habitat where the plants did not suffer from Fusarium wilt. It is therefore highly likely that Chaetomium may play an important role in the development of Fusarium wilt in plantains and banana. In the study reported here, it is possible that $C$. globosum had contributed towards the disease symptoms observed. This is more so because this fungus was isolated from all parts of the plant, as well as from the fruiting body which was seen in all macro propagators during the survey.

Alternaria spp. have been isolated frequently during surveys of endophytes in the xylem and stem tissues of plants, in the leaves of important medicinal plants (Kurandawad and Lakshman, 2011), and in the shoots and leaves of Vistis vinifera (Mostert et al., 2000). Moreover, Thomma (2003) reported that most Alternaria species are saprophytes that are commonly found in soil or decaying plant tissues which could possibly imply an association between this species and the corm rot observed in the macro propagators in this study. Alternaria alternata has been associated with Alternaria leaf spot of ornamental dwarf banana in China (Fu et al. 2014). Although this fungus has not been associated with any disease on edible bananas in Cameroon and the rest of the world, it is likely that its activities may have deleterious effects on the growth and development of bananas and plantains.

Isolate $\mathrm{L}$ was identified as Trichoderma harzianum while isolate $\mathrm{R}$ was Hypocrea lixii. Chaverri and Samuels (2002) revealed that Hypocrea lixii is the teleomorph (sexual stage) of Trichoderma harzianum which is the anamorph (asexual stage) of the same species. Therefore, isolates $\mathrm{L}$ and $\mathrm{R}$ which were initially considered as different species based on micro-morphological characteristics were found to be different stages of the same species based on molecular techniques. Although no literature that associates $T$. harzianum and plantain has been encountered so far, it has been reported that Trichoderma harzianum is a common soil species and is used in biological control of a variety of plant-pathogenic fungi. It has been isolated from the rhizosphere of banana (Haryono, 2007). T. harzianum is effective against pathogenic fungi and diseases such as Rhizoctonia solani root rots, Phytophthora megasperma f. sp. glycine a root rot on soybean, Gaeumannomyces gramminis takeall of wheat, Sclerotinia sclerotiorum rots, Sclerotium rolfsii Southern stem blight of tomato, and Fusarium wilt of tomatoes 
(Gnancadja et al., 2015). In addition to the bio-control properties of $T$. harzianum, this species has potential for the enhancement of plant growth and resistance to plant pathogens (Ouedraogo and Hien, 2015). It is therefore unlikely that this species is implicated in the diseased symptoms observed.

\section{Conclusion}

From our findings, it is very likely that Fusarium and Chaetomium were the causative organisms for the corm rot and blight symptoms observed in macro propagators in Buea. Proper management and control of these fungi in propagators will therefore permit the production of healthy seedlings, thus making them available to farmers. The availability of these seedlings will guarantee large scale production of plantains.

\section{COMPETING INTERESTS}

The authors declare that they have no competing interests.

\section{AUTHORS' CONTRIBUTIONS}

ETB conceived, designed and supervised the research, YAA collected data and samples from the field, analyzed the samples in lab-based experiments under the supervision of ETB, ETB and YAA contributed in drafting the manuscript.

\section{ACKNOWLEDGEMENTS}

Authors would like to acknowledge Professor Fidelis Cho Ngwa for allowing us to use the Biotechnology Unit of the University of Buea for the Molecular aspects of this research. We are also thankful to Ms Joice Meshi for technical support. We appreciate the comments from the anonymous reviewers, which have helped us to improve the quality of the manuscript.

\section{REFERENCES}

Abou A, Shebany Y. 2012. Endophytic Chaetomium globosum enhances maize seedling copper stress tolerance. Plant Biology, 14(5): 859-
863. 8677.2012.00608.x

DOI:10.1111/j.1438-

Baiyeri KP, Ajayi AR. 2000. Status and Constraints of Musa spp. Production in a Sub-humid Zone of Nigeria. Acta Horticulturae, 540: 72- 80.

Biles C, Wright D, Fuego M, Guinn A, Cluck T, Young J, Martin M, Biles J, Poudyal S. 2012. Differential Chlorate Inhibition of Chaetomium globosum Germination, Hyphal Growth, and Perithecia Synthesis. Mycopathologia, 174: $\quad$ 475487.DOI. http://doi.org/10.1007/s11046012-9572-5

Chaverri P, Samuels G, 2002. Hypocrea lixii Pat., the teleomorph of Trichoderma harzianum Rifai. Mycol. Prog., 1: 283286.DOI.http://doi.org/10.1007/s11557006-0025-8

Fu BZ, Zhang ZH, Wang LH, Li G, Zhang JZ, Zhang Y. 2014. First report of leaf spot caused by Alternaria alternata on Chinese dwarf banana in China. Plant Disease, 98(5): 691. DOI: 10.1094/PDIS-08-130831-PDN

Gandonou CB, Ahanhanzo C, Agbangla C, Agbidinoukoun A, Doussoh A, Cacaï G, Dossoukperi R. 2012. Micropropagation in vitro de la variété locale «Aloga» du bananier plantain (Musa x paradisiaca L.) au Benin. Int. J. Biol. Chem. Sci., 6(3): 1102-1111.

DOI: http://dx.doi.org/10.4314/ijbcs.v6i3.16

Ghag SB, Shekhawat UKS, Ganapathi TR. 2015. Fusarium wilt of banana: biology, epidemiology and management. International Journal of Pest Management, 61(3): 250-263. DOI: https://doi.org/10.1080/09670874.2015.10 43972

Gnancadja LS, Tonon DHE, Faton EMO, Douro Kpindou KO, Dannon E, Akoegninou A. 2015. Efficacité de l'agent antagoniste Trichoderma harzianum sur Fusarium oxysporum f. sp. lycopersici agent pathogène de la tomate. Int, J. Biol. Chem. Sci., 9(2): 770-782. DOI: http://dx.doi.org/10.4314/ijbcs.v9i2.17

Hallman J, Berg G, Schulz B. 2007. Isolation Procedures for Endophytic Fungi Microorganisms. Springer Brelin Heidelberg: New York.

Haryono J. 2007. Biological suppression of 
seedling banana heart rot at TP Nusantara Tropical Fruit, Lumpung. BSc. Thesis, Jenderal Soerdirman University, Indonesia.

Kahangi EM, Muthee AM, Chege BK. 2004. Constraints and sustainable solutions for adoption of TC banana technology and marketing. Acta Hort. (International Society for Horticultural Science), 638: 441-447. DOI: http://www.actahort.org/books/638/638_5 6.htm

Koné D. 2008. Contribution à l'étude des champignons épiphylles des bananiers en Côte d'Ivoire: Caractérisation morphologique et pathologique de Mycosphaerella fijiensis var. difformis Morelet, Cladosporium musae Mason, Deightoniella torulosa (Syd.)

Ellis et Cordana musae Zim.; sensibilité à quelques fongicides. Thèse de Doctorat d'Etat. Université de Cocody, Côte d'Ivoire, p. 244.

Kornerup A, Wanscher IH. 1978. Methuen Handbook of Colour. Eyre Methuen Ltd.

Kurandawad JM, Lakshman HC. 2011. Studies on endophytic fungal diversity in some important medicinal plants of the botanical garden: a report. J Theor Exp Biol., 8: 45-51.

Liu D, Coloe S, Baird R, Pedersen J. 2000. Rapid mini-preparation of fungal DNA for PCR. Journal of Clinical Microbiology, 38(1): 471. DOI: http://jcm.asm.org/content/38/1/471.

Michaelsen A, Pinzari F, Ripka K, Lubitz W, Pinar G. 2006. Application of molecular techniques for identification of fungal communities colonizing paper material. International Biodeterioration and Biodegradation, 58: 33-141. DOI: http://doi.org/10.1016/j.ibiod.2006.06.019

Mostert L, Crous PW, Petrini O.2000. Endophytic fungi associated with shoots and leaves of Vistis vinifera, with specific reference to the Phomopsis viticola complex. Sydowia, 52: $\quad 46-58$. DOI:

http://hdl.handle.net/20.500.11755/034fle 0e-ff18-40cc-868d-19f8895654ce
Njau N, Mwangi M,Gathu R,Mbaka J,Muasya R. 2011. Banana weevil (Cosmopolites sordidus) reduces availability of corms for seedling production through macropropagation technology. J. Anim. Plant Sc., 12(1): 1537-1542.

Ngoh NG, Tchango TJ, Fokou E, Etoa FX. 2005. Processing and food uses of bananas and plantains in Cameroon. Fruits, $\quad$ 60(4): 245-253. DOI: http://doi.org/10.1051/ fruits:2005031

Okoro CC, Amund OO, Eliora R. 2009. Plasmids of phenanthrene and dibenzothiophene-degrading bacteria isolated from produced water samples in oil production. Int. J. Biol. Chem. Sci., 3(2): $\quad$ 186-191. DOI: http://dx.doi.org/10.4314/ijbcs.v3i2.44501

Ouedraogo E, Hien E (2015). Effet d'un compost enrichi par des spores du clone Trichoderma harzianum (rifaï) sur le rendement du niebé et du mais sous abris au Burkina Faso. Int. J. Biol. Chem. Sci., 9(3): $\quad 1330-1340 . \quad$ DOI: http://dx.doi.org/10.4314/ijbcs.v9i3.18

Singh HP, Uma S, Selvarajan R, Karihaloo JL. 2011. Micropropagation for Production of Quality Banana Planting Material in Asia-Pacific. Asia-Pacific Consortium on Agricultural Biotechnology (APCoAB): New Delhi, India; 92.

Sudarma MI, Suprapta DN. 2011. Diversity of soil microorganisms in banana habitats with and without Fusarium wilt symptom. J.ISSAAS 17(1): 147-159.

Thomma BP. 2003. Alternaria spp.: from general saprophyte to specific parasite. Mol. Plant Pathol., 4(4): 225-236. DOI: 10.1046/j.1364-3703.2003.00173.x.

Watanabe T. 2002. Pictorial Atlas of Soil and Seed Fungi: Morphologies of Cultured Fungi and Key to Species (2nd edn). CRC Press LLC.

Zhang GZ, Zhang YH, Qin JC, Qu XY, Liu JL, Li X, Pan HY. 2013. Antifungal metabolites produced by Chaetomium globosum No.04, an endophytic fungus isolated from Ginkgo biloba. Indian J. Microbiol., 53: 175-180. DOI: https://link.springer.com/article/10.1007/s 12088-013-0362-7 